\title{
Debutanter om selvmord. Hvor eksplisitt kan man skildre?
}

\section{Anmeldelse ved Kari Wille Rekdal}

Selvmord har vært både motiv og tema i litteraturen i mange hundre år, men forst da Johann Wolfgang von Goethes roman Den unge Werthers lidelser utkom i 1774, ble litterære selvmordsskildringer et problem, fordi romanen visstnok førte til at mange unge menn fulgte i romanpersonens fotspor og tok sitt eget liv. Werther-effekten, det at en for detaljert eller nærgående presseomtale av selvmord kan bli inspirasjonskilde for andre, har fått sitt navn nettopp etter denne boken. Derfor har pressen pålagt seg selv strenge restriksjoner for hvordan den kan omtale selvmord. Brudd på disse restriksjonene kan påklages til Pressens faglige utvalg. Litteraturen på sin side har ikke pålagt seg selv noen slike restriksjoner, utover forfatters og forlags egne etiske kompass. I forrige nummer av Suicidologi var temaet medieomtale av suicidal atferd og smitteeffekt, der jeg selv forsøkte å ramme inn problemstillingen med selvmordsskildringer i skjønnlitteraturen (Rekdal 2016).

I litteraturen i vår egen tid, i norsk samtidslitteratur, skrives det mye som er så virkelighetsnært, ligger så tett på forfatterens eget liv, at skillet mellom fiksjon og virkelighet blir svært utydelig, og noen ganger usynlig. Det har de siste månedene vært en debatt om i hvor stor grad en forfatter har rett til å bruke eget liv som stoff når det også trekker inn andre mennesker som uten å ha bedt om det blir lett gienkjennelige fiksjonskarakterer, uten muligheter til å gi sin version av hendelsene. Den debatten skal jeg ikke gå inn i her. Men også selvmordsskildringer dukker opp i litteraturen, noen så presist og detaljert skildret

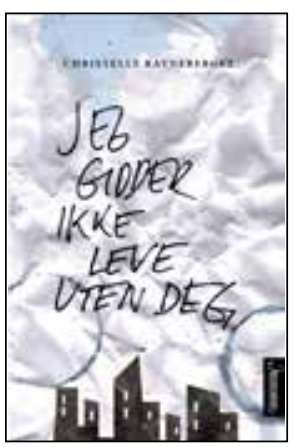

CHRISTELLE RAVNEBERGET:

Jeg gidder ikke leve uten deg.

Roman. Aschehoug 2015
Christelle Ravneberget:

\section{Jeg gidder ikke leve uten deg}

Ravneberget skildrer et hipt storbymiliø av unge, uetablerte voksne mennesker som er opptatt av musikk og rus. Hovedmotivet i romanen er den destruktive kjærlighetshistorien mellom Annabel og Christian. Synsvinkelen ligger hos Annabel, en arbeidsløs kunstner, det er hun som forteller. Christian spiller i band, og det er kjærlighet ved første blikk mellom de to, beskrevet på en måte som gir assosiasjoner til Joachim Nilsens tekster. Og det er da også Jokke som Christian siterer når han og Annabel møtes: «Du er jævla pen. Ikke pen på den pene måten, bare vakker for meg.» I det hele tatt finnes det mange referanser til musikkt- at Vær varsom-plakaten ville ha hindret en tilsvarende artikkel i å bli trykket i noen avis. Ropet på en Vær varsom-plakat og etiske retningslinjer for litteraturen lyder stadig, både i avisspaltene og i sosiale medier. Det viktigste akkurat nå, tror jeg, er nettopp at dette debatteres. Og så må man heller ikke glemme leserens rolle i fortolkningen. Hva forfatteren skriver og leseren leser, er ikke samme sak.

Høsten 2015 var det påfallende mange selvmordsmotiv i norske bøker. Tre unge debutanter skrev alle om unge mennesker som snakker om, prøver eller faktisk giennomfører å ta livet sitt. Det dreier seg her om en novellesamling og to romaner. Fellestrekkene er at forfatterne er unge, de er debutanter, de skriver om hvor vanskelig livet kan kjennes også i vår svært privilegerte del av verden, og selvmord er motiv i alle tre. Men det er også store ulikheter mellom de tre utgivelsene. Bøkene jeg skal omtale er Christelle Ravnebergets leg gidder ikke leve uten deg, Runar Mykletuns Repetisjonsøvelse, og Tora Ordahl Mikkelborgs Ennå er det tid.

Ravnebergets bok er den mest lettleste og underholdende, men det betyr ikke at den mangler substans. Mykletuns bok er den som best skildrer hvordan en familie sprenges i fillebiter når et familiemedlem tar livet sitt, og språklig er det denne som har mest å sette tennene i. Mikkelborg pløyer i sine noveller dypest i det menneskelige mørket, det vi alle har inni oss, men helst ikke vil utforske.

Jeg vil først omtale disse tre bøkene hver for seg, for så å komme med noen oppsummerende betraktninger til slutt. ekster i boken, noe som fungerer veldig bra og forsterker opplevelsen av de menneskene og det miljøet Ravneberget skildrer. Forelskelsen mellom Christian og Annabel er altoppslukende, tar ingen hensyn til tilværelsen ellers, og har mange paralleller til rus, som boken også inneholder mange skildringer av. «Kan man ta overdose på kjærlighet? Kan man dø av kjærlighet?» tenker Annabel etter at hun har møtt Christian. Det destruktive kjærlighetsforholdet er selvfølgelig ikke liv laga; Annabel og Christian er Sailor og Lulu, Bonnie og Clyde, Honey Bun og Pumpkin, og leseren skjønner fort at dette ikke kan ende godt.

Før Annabel treffer Christian, tenker hun ofte på selvmord. Ikke på en deprimert eller planleggende måte, mer som innskytelse, en talemåte. "Skal jeg bare ta livet av meg, eller lage kaffe? Skal jeg drikke kaffe, har vi i det hele tatt kaffe, eller hoppe ut av vinduet?» Det blir kaffe.

Lek med selvmordstanker og destruktiv kjærlighet kan lyde som klisjeer, det samme gielder romanens tittel, men boken redder seg fint unna, mye på grunn av språket, som er roft og muntlig, men flyter bra og gir god driv i fortellingen. 
Det er høyt tempo og mye lidenskap. Tilbake til tittelen: Den virker overflatisk ved første øyekast, en slags tilværelsens uutholdelige letthet for ungdom uten egentlige problemer. Etter hvert tenker leseren at det er jeg-personen Annabel som ikke gidder å leve. Helt frem til slutten av boken der det viser seg at ordene er Christians, i et brev han sender Annabel før han tar livet sitt. Han drukner seg, vi får ikke vite mer enn det.

«Alt skjedde, og ingenting skjedde. Det var i går det begynte, og nå har det slutta.»

Slik slutter boken til Ravneberget.

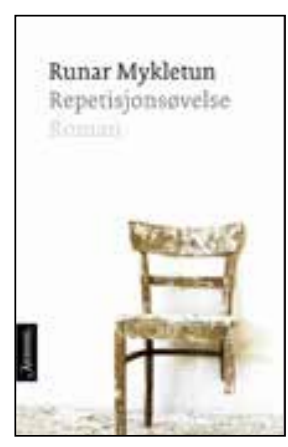

\section{Runar Mykletun: Repetisjonsøvelse}

I denne romanen har selvmordet skjedd ti år før fortellingen starter. Forfatteren viser oss konsekvensene av det, hvordan familien som sitter igien forsøker å pusle sammen tilværelsens biter. Nitten år gamle Ole har tatt livet sitt, og moren Anette, faren Torfinn, broren Endre og søsteren Irene ser tilbake på hvert sitt vis, husker den døde på hvert sitt vis, forsøker å leve videre på hvert sitt vis. Den tilbakeskuende fortellingen er for det meste skildret i presens,
RUNAR MYKLETUN: Repetisjonsøvelse Roman. Aschehoug 2015. og den binder sømløst sammen episodene i fortid, nåtid og fremtid. Det er et litterært sett dristig prosjekt Mykletun har lagt ut på, og han kommer stort sett svært heldig fra det.

Det er Endre som finner den døde, og selvmordet har skjedd ute i skogen ved henging. Den døde har hengt en stund, og leseren får en nokså grafisk beskrivelse både av hva som skjer ved henging, og av hvordan liket ser ut. Endre studerer senere medisin, blir lege, men så dør en av pasientene hans, kanskje er det Endres skyld, kanskje ikke, men det utløser noe i ham, et forsinket sammenbrudd. Han søker permisjon fra sykehusjobben og reiser hiem til mor.

Irene forsøker å studere, men faller fort ut av studenttilværelsen. Hun fungerer dårlig sosialt, har antagelig en forhistorie med spiseforstyrrelse, og blir et lett bytte for en religiøs sekt. Hun blir et Lysets barn, bryter kontakten med familien, og gifter seg med et sektmedlem.

Faren Torfinn har underslått midlene i minnefondet de har etablert etter Ole. Han stikker av med regnskapsføreren og drar til Frankrike på kanalbåtferie, i et nokså håpløst forsøk på å finne tilbake til noe, til noen han en gang var.

I Mykletuns skildring er selvmordet en sprengkraft som slynger familiemedlemmene fra hverandre, ut i ulike baner. Men så trekkes de mot hverandre igien ti år senere, mot moren som ikke har reist noe sted, men har blitt værende i familiehjemmet, som et nav de andre sirkler rundt, en planet de har gått i bane omkring. Er hiemkomsten en repetisjonsøvelse for familien? Kommer de tilbake for å gienoppleve, rekonstruere, gienopprette, finne tilbake? Er det en form for hiemlengsel? Frem og tilbake, men de er like langt, de fremstår som like dysfunksjonelle, selv om de tidligere fremsto vanlige på overflaten. Var det noe som lå i familien på forhånd, som et frø som bare ventet på de rette betingelsene for å spire, eller var det selvmordet og ingenting annet som forårsaket sammenbrudd i alle strukturer? Teksten gir ikke noe klart svar, men åpner for ulike forståelser. Tittelen gir en antydning om at de ikke har lært noe av det som har skjedd, det har ikke vært noe oppgiør, noen renselse, noen felles samtale om brorens død, tvert imot beholder de sine ulike oppfatninger av ham. Ved hiemkomsten når de igien er samlet, er alt som før, og ingenting er som før. Repetisjonsøvelsen består i å gienta alt det som ikke fungerte, men også å prøve å finne sammen. Men er det mulig å gienopprette, finne mening, etter noe så meningsløst som at noen har tatt livet sitt? Teksten gir som nevnt ingen klare svar, men nettopp det at teksten er så åpen for tolkning, giør at leseren kan vende tilbake til den på nytt og på nytt og stadig finne nye innfallsvinkler.

Sluttscenen skildrer familien rundt bordet. Det er moren Anette som får det siste ordet. Hun orker ikke se bort på mannen, men hviler blikket på Endre: «- Han har fått litt farge, har han ikke?» Hun betrakter Irene, som ligner på henne selv, og som ikke har blitt den moren hadde håpet hun skulle bli. Ingen snakker om Ole. «Hun kremter, retter seg opp i ryggen, sier; vær så god.»

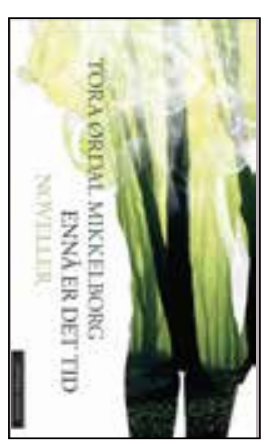

Tora Ørdal Mikkelborg: Ennå er det tid

Mikkelborgs noveller stryker ikke akkurat leseren med hårene. Det er seks stykker av dem og flere av dem er svært lange til noveller å være. Av plasshensyn skal jeg bare ta for meg to av dem; tittelnovellen «Ennå er det tid», og «Snart skal jeg ikke tilbake hit».

Alle tekstene er jeg-fortellinger, alle jeg-ene har et åpenbart behov for å fortelle, bekjenne, fortolke, forstå. I god novelletradisjon brettes det som hendte,

TORA ØRDAL

MIKKELBORG:

Ennå er det tid

Noveller.

Cappelen Damm. langsomt ut for leseren. Det hele er fortalt i et sterkt språk, med gode observasioner både av naturen og det kroppslige, og menneskene som skrives frem, er levende vesener av kjøtt og blod. Men det er smertefullt og hardt, i hvert fall klarte ikke jeg å lese enkelte av novellene uten å ta pauser fra det vonde.

I tittelnovellen «Ennå er det tid» møter vi en trettenårig storesøster som plager lillesøsteren, virkelig plager, det er stygt og sadistisk, nesten. Så faller lillesøsteren av sykkelen og blir drept mens hun sykler sin vei etter en omgang med denne plagingen. Familien faller sammen, de klarer ikke å ta vare på hverandre i sorgen, begge foreldrene har nok med sin egen smerte. Hovedpersonen tenker på hvordan alle, slektninger, venner, naboer, lokalsamfunn, stilte opp da lillesøsteren døde. Og hvordan de ganske raskt ble borte igien. For de andre er verden tilbake i sitt vante spor, men ikke for familien som sitter igien. For dem har tilværelsen gått over i en ny tidsregning, slik det blir etter et brått og uventet dødsfall. En asymmetri som setter opp usynlige skillevegger mellom oss som har opplevd et slikt tap, og de andre. «Det har gått et halvt år, og vi skal leve videre. Huset er tomt. Alle menneskene har gått og ingen av dem har kommet tilbake. Blomstene har visna for lenge sida.»

Storesøsteren venter på at nå, nå skal faren oppdage henne, at han har en datter til, samtidig som hun nesten går til grunne av anger og skyldfølelse og av å bære det alene. «Alt som er 
min skyld», tenker storesøsteren der de tre gienlevende, mor, far og hun selv, sitter sammen rundt middagsbordet. Og hun fortsetter å håpe, som Nora Helmer, «at det vidunderlige skal skje»; at pappa ser henne. Det er en situasion som mange unge mennesker har opplevd når et søsken har tatt livet sitt; at de også på et vis mister foreldrene sine, og at den som er død, tar så mye plass, mye mer plass enn et søsken i live noen gang har giort.

«Men så ser pappa på meg. Han smiler. Drar hånda giennom skjegget og forsyner seg med maten. Og jeg smiler så vidt tilbake. For ennå er det tid. Ennå kan han legge armene sine rundt meg og si, vi har jo fortsatt deg.»

Selvmordsskildringen dukker opp i novellen "Snart skal jeg ikke tilbake hit». Her manes barndommen frem når jeg-fortelleren kommer tilbake til barndomshjemmet for å rydde etter foreldrenes død. I bakgrunnen ligger det en stygg historie om seksuelle overgrep begått av den eldre fetteren Ion. Fetteren har en psykisk lidelse av en eller annen art, og jevnlig stikker han av, ut i skogen for å henge seg, og da må hele familien og nabolaget ut og lete. Jeg-personen tenker på hvordan hun som barn lå i sengen sent om kvelden og hørte faren og de andre rope der ute i skogen, «on! Jon!» Men det snakkes ikke høyt om at Jon er syk, det er ikke-tema i familien. På samme måte som det ties om alt annet som er vanskelig eller unevnelig.

Overgrepene skjer ute i den samme skogen, og jeg-personen føler uklart, slik barn ofte giør, at dette er noe hun må giøre, det er hennes skyld og ansvar, og ikke Jons. Det ender med en voldtekt i form av et fullbyrdet samleie, jeg-personen blir liggende igien på bakken i skogen mens Jon løper bort. Før hun rekker å komme seg opp og få klærne på plass, dukker faren hennes opp. Det er uklart hvor mye han har sett, men det er ingen tvil om at han forstår hva som har skjedd. "Så, så, sa han. Så, så, så.» Deretter går de sammen hjem. Når de nærmer seg huset de bor i, stanser faren og sier, «- dette kan vi ikke fortelle til noen.»

Den kvelden forsvinner Jon igien, og faren er med ut for å lete. Jeg-personen hører ropene, og så står hun opp igien og går ut i skogen. Hun finner fetteren sittende på en tykk gren oppe i et tre, med repet klargiort sitter han og klamrer seg til stammen. Jeg-personen tar en gren fra et rognetre og slår til Ion slik at han mister taket der han sitter, og han henger seg / blir hengt. Beskrivelsen av hvordan han faller og hvordan han dør, er ganske detaljert. Da hun snur seg og går fra den døde for å gå hiem igien, oppdager hun at faren har sett det hele. De snakker aldri om det. På samme måte som med voldtekten, er dette noe de ikke kan fortelle til noen.

«Senere har jeg tenkt at det å se noen dø, det er det mest private et menneske kan bevitne», erkjenner jeg-personen i nåtid. Dette er en eksistensiell betraktning for vår tid, der vi, parallelt med en uhemmet åpenhet og fremvisning av kropp og kiønn og alt seksuelt, har en slik angst for døden og døde mennesker at knapt noen av oss har sett et dødt menneske, langt mindre noen som dør. Samtidig kobler utsagnet eros med thanatos og understreker slik likheten mellom de to scenene i skogen; det ufrivillige samleiet og det ufrivillige selvmordet.

\section{Eksplisitte skildringer av selvmord - fritt frem for skjønnlitteraturen?}

Selv om disse tre debutantene ikke er alene om å skildre selvmord litterært, er de tre utgivelsene et godt utgangspunkt for refleksjon rundt i hvilken grad selvmord kan eller skal beskrives.

Her er Ravneberget den minst problematiske etter mitt syn. For det første gis det ingen nærgående skildring av metode i teksten, det bare fortelles kort at Christian er død, og at han har druknet seg. At hovedpersonens tanker om å ta livet sitt giengis eksplisitt i teksten, ser jeg ikke som problematisk i den konteksten de fremstilles.

Skildringen i Mikkelborgs novelle er derimot mer foruroligende. Selv om den ikke gir noen direkte oppskrift på hvordan man går frem for å henge seg (det tror jeg de fleste vet allerede), så er beskrivelsen så detaljert at den i alle fall ikke kunne vært trykket i en artikkel. Men er den dermed over grensen for hva som er forsvarlig i en novelle?

Likeledes er skildringen hos Mykletun, der Endre finner broren død, både foruroligende og svært ubehagelig å lese. Den dødes tilstand beskrives ganske detaljert. Ingunn Økland var ganske skeptisk til romanens eksplisitte skildring da hun omtalte disse samme bøkene i Aftenposten:

«Det er en mer gienkjennelig fare på ferde hos Runar Mykletun. Visse partier i Repetisjonsøvelse er det faktisk diskutabelt å giengi i en avis. For Mykletun beskriver ikke bare metoden for selvmordet, han skildrer dessuten åstedet og likets beskaffenhet.» (Økland 2015)

Kan vi dermed konkludere med at en slik beskrivelse kan ha smitteeffekt? Det er vanskelig å gi et kategorisk svar. Men det er interessant å merke seg at den teksten jeg synes gir leseren mest å bryne seg på av disse tre, også er den som er mest problematisk med tanke på en eventuell smitteeffekt. Bør noen skjønnlitterære verker utstyres med en helseadvarsel til folk med suicidale tanker? Antakelig ville en slik advarsel fungere akkurat motsatt.

Psykologspesialist Eivind Normann-Eide har skrevet bok om selvmord i skjønnlitteraturen. I et interviu med Klassekampen sier han:

«Det som kjennetegner gode litterære beskrivelser av selvmord, er at de nettopp viser hvor komplekst selve forløpet er. Det er også en viktig grunn til at jeg tror romaner kan bidra med perspektiver som giør at vi forstår selvmordet på en mer nyansert måte.»

Dette utsagnet er dekkende for de tre verkene som er omtalt her, og jeg tror det er et riktig utgangspunkt for denne debatten. Vi kommer ikke forbi at vi trenger skjønnlitteraturen og dens muligheter til å skildre det som ikke pressen kan. Kunstneriske forsøk på å beskrive det ubeskrivelige, det unevnelige, er av helt grunnleggende betydning for oss som mennesker. Det skjønnlitterære rommet har sin styrke i at det åpner nettopp for å snakke om det som er unevnelig, uutholdelig, men det må ikke bli noe forfatteren kan giemme seg bak. Ansvaret for det som skrives, hviler på henne uansett.

\section{REFERANSER:}

Larsen, D.E.U. (2016). Søker etter svar i litteraturen. Klassekampen 7. november, 22-23.

Normann-Eide, E. (2016). Skjønnlitterære selvmord: Pax.

Rekdal, K. (2016). Torre der andre må tie - fritt frem for selvmordsskildringer i litteraturen? Suicidologi 21 (2), 10-14.

Okland, I.(2015). Kunsten er frisone for selvmordet. Aftenposten 6. september, del 2, 8-9. 